\title{
Association of Bone Morphogenic Protein Receptor IA (BMPIA) Gene Polymorphism with Ossification of Posterior Longitudinal Ligament (OPLL) of the Cervical Spine in a Chinese Han Population
}

\author{
Weitao Jin ${ }^{1}$, Hui Yang ${ }^{1}$, Chunli Zhao ${ }^{2}$, Xin Lin ${ }^{2 *}$ and Hao Wang'
}

${ }^{1}$ Beijing Institute for Neuroscience, Beijing Center of Neural Regeneration and Repair, Key Laboratory for Neurodegenerative Disease of the Ministry of Education, Capital Medical University (CMU), Beijing, China

${ }^{2}$ Beijing Tiantan Hospital, Capital Medical University (CMU), Beijing, 100050 China

\begin{abstract}
Study design: A case-control study using radiograph findings and the PCR assay with regard to the susceptibility and the severity of ossification of posterior longitudinal ligament of the spine (OPLL).
\end{abstract}

Objective: To analyze whether the single nucleotide polymorphisms in the Bone Morphogenetic Protein Receptor IA (BMPIA) gene predisposed to increased the frequency and severity of OPLL.

Methods: Analysis of 292 OPLL patients and 586 non-OPLL controls was performed. Radiographs of the cervical spine were analyzed to determine whether OPLL was present and to what degree. Genomic DNA was extracted from all participants. Polymorphisms of the BMPRIA gene were analyzed using the PCR assay. The association of the polymorphisms with the development and extent of OPLL were statistically evaluated.

Results: Significant associations were found between two single nucleotide polymorphisms (rs34755052, rs 11528010) and the existence of OPLL in BMPRIA genes. Both of rs34755052 (C/T) and rs11528010 (C/A) were more frequent in patients with OPLL. Regarding the rs11528010 (C/A), patient with A Allele had a significantly greater number of ossified cervical vertebrae compared with patients without the A allele, but rs34755052 didn't show the similar tendency.

Conclusion: The present results suggested that rs34755052(C/T) was associated with the occurrence of OPLL, but not associated with the severity of OPLL. rs11528010(C/A) was associated with more extensive OPLL and the frequency with which it occured.

Keywords: Bone Morphogenetic Protein Receptor IA gene (BMPIA); Ossification of the posterior longitudinal (OPLL); Single Nucleotide Polymorphism (SNP); Cervical spine; Case-control study

\section{Introduction}

Ossification of the posterior longitudinal ligament (OPLL) is characterized by ectopic calcification of ligamentous tissues of the spine. The new calcificated clot often compressed the spinal cord and nerve roots which resulted in various degrees of myeloradiculopathy $[1,2]$. OPLL of the spine had been reported in Asian populations with a prevalence of $1.9 \%-4.3 \%$ in Japanese (aged $>30$ years) and $0.44 \%$ $8.92 \%$ in Chinese [3-7]. Although a lot of factors, such as high body mass index (BMI), high peripheral bone mineral density (BMD), dietary habits, aging and glucose intolerance, had been reported to have various extent relationships with OPLL, the etiology of OPLL was still not clear until now [8-12]. Genetic background was considered to be an important factor in the development of OPLL on the basis of pedigree surveys, family study of twins and analysis of human leukocyte antigen haplotypes [13-16]. And previous studies had shown that single nucleotide polymorphisms (SNPs) in the transforming growth factor- $\beta$, nucleotide pyrophosphatase (NPPS), leptin receptor, collagen 6A1 (COL6A1), bone morphogenetic protein 2 (BMP2) and bone morphogenetic protein 4 (BMP4) as well as estrogen receptor (ER) and interleukin-1 (IL-1) genes were associated with the development of OPLL [17-21]. However, only BMPs were able to induce ectopic ossification when these factors were injected into animal models [22]. Our group had previously demonstrated that some SNPs in BMP2 and BMP4 gene were associated with the occurrence and severity of OPLL in a Chinese population, although little evaluation of the clinical and demographic backgrounds of the participants was carried out $[18,23]$. In this study we focused on the role of Bone morphogenetic protein receptor IA (BMPRIA) in the development of OPLL.
BMPRIA was one subtype of the bone morphogenetic protein receptor family [24]. Previous studies had demonstrated that BMPRIA was an important regulator in the signal transduction of BMP pathway $[25,26]$. Analysis of the osteogenic activities of the bone marrow stromal cells demonstrated that over expression of BMPRIA was one of the most potent inducers of osteogenic differentiation in vitro [27] and in animal model [28]. Additional case-control studies of fibrodysplasia ossificans progressiva and adolescent idiopathic scoliosis also showed BMPRIA to be a potent modulator of cartilage development in vivo and inhibition of BMP type I receptor activity might be useful in treating heterotopic ossification syndromes [29,30]. Interestingly, pathological studies found that bone morphogenetic protein receptors were highly expressed in ossified ligament tissues of patients with ossification of the posterior longitudinal ligament $[31,32]$, which implied BMPRIA might play an important role in the development of OPLL. Most recently, Liu et al. observed the variation in BMPR1A gene would result in over expression of BMPRIA, which had been considered to be an indicator to cells' osteogenic potential [33]. Up to know no previous studies had assessed BMPRIA variations. In the current study we hypothesized

*Corresponding author: Xin Lin, Beijing Tiantan Hospital, Capital Medical University (CMU), Beijing, 100050 China, E-mail: drlinxin@gmail.com

Received September 27, 2012; Accepted December 27, 2012; Published December 29, 2012

Citation: Jin W, Yang H, Zhao C, Lin X, Wang H (2013) Association of Bone Morphogenic Protein Receptor IA (BMPIA) Gene Polymorphism with Ossification of Posterior Longitudinal Ligament (OPLL) of the Cervical Spine in a Chinese Han Population. J Spine 2: 131. doi:10.4172/2165-7939.1000131

Copyright: (c) 2013 Jin W, et al. This is an open-access article distributed under the terms of the Creative Commons Attribution License, which permits unrestricted use, distribution, and reproduction in any medium, provided the original author and source are credited. 
Citation: Jin W, Yang H, Zhao C, Lin X, Wang H (2013) Association of Bone Morphogenic Protein Receptor IA (BMPIA) Gene Polymorphism with Ossification of Posterior Longitudinal Ligament (OPLL) of the Cervical Spine in a Chinese Han Population. J Spine 2: 131. doi:10.4172/21657939.1000131

Page 2 of 5

that BMPRIA might be involved in OPLL, and we evaluated the overall polymorphisms of the BMPRIA gene in a large group of Chinese patients with OPLL.

\section{Materials and Methods}

\section{Participants}

A total of 292 cervical OPLL patients and 586 age-and sexmatched non-OPLL controls were investigated in this study. All the characteristics of the OPLL patients and controls were shown in table 1 . This study was approved by the Ethical Committee of Beijing Tiantan Hospital, Capital Medical University. Informed consent was obtained from all the participants including in this study. The diagnosis of OPLL was established based on the sagittal section of computed tomography (CT) of the cervical spine according to the criteria reported by Tsuyama. The severity of OPLL was determined based on the number of ossified vertebrae on these CT films, and patients were also stratified according to the extent of ossification [34]. Based on the radiological and laboratory examinations, patients with ankylosing spondylitis and metabolic diseases, such as hypophosphate rickets, osteomalacia, osteoporosis, diffuse idiopathic skeletal hyperostosis (DISH) and hyperparathyroidism were excluded. Patients who have taken medicines such as estrogen, progesterone, glucocorticoids, bisphosphonates, alfacalcidol and calcitriol were also excluded from this study.

Blood samples were collected from all participants. The study protocol was approved by the ethical committee of Beijing Tiantan Hospital, Capital Medical University and written informed consent was obtained from all participants before the study.

\section{Genomic DNA analysis}

Peripheral blood samples were collected in tubes containing ethylene diamine tetraacetic acid (EDTA, $50 \mathrm{mmol} / \mathrm{L}$ of disodium salt), and stored at $-20^{\circ} \mathrm{C}$ until use for genomic DNA extraction and genotyping. Genomic DNA was extracted from peripheral blood leukocytes using a Wizard Genomic DNA Purification Kit (Promega, Madison, WI, USA). The BMPRIA gene was amplified by the polymerase chain reaction (PCR) with a standard protocol [35] in a total of 5 overlapping fragments and sequenced. The reactions were performed. Different thermocycling parameters were used for different primer pairs. Sequencing reactions were performed using the
Big Dye Terminator v3.1 Cycle Sequencing Kit (Applied Biosystems, Foster City, CA, USA), and the extension products were analyzed on an ABI 3730XL POP7 DNA sequencing analysis 5.2 system (Applied Biosystems). All described data about polymorphisms were discovered in our study, but before our experiments, all these rs-ID (rs 34755052, rs 113347633 , rs 11528010 , rs 35619497 , rs 17231982 , rs 6586039 , rs 11202203 , rs 10887666 , rs 7922846 , rs 2354354 , rs 10788528 , rs 19947684) have also been reported in GeneBank. SNPs with unknown heterozygosity and minor allele frequencies below $5 \%$ were excluded.

\section{Statistical analysis}

Hardy-Weinberg equilibrium and the genotypic and allelic distribution were evaluated using $\chi^{2}$ tests. The characteristics of two groups were compared using Student unpaired $t$ test and the genotype distribution in BMPRIA between two groups were compared by chisquared tests. The nonparametric Mann-Whitney $U$ test was used to compare the number of ossified cervical vertebrae between the two groups. Data were expressed as means \pm SD, and analyzed with SPSS 16.0 software (SPSS, Chicago, IL) A $p$ value less than 0.05 was considered statistically significant.

\section{Results}

The clinical and demographic characteristics of the patients with OPLL and control were shown in table 1 . There were no significant differences in age, gender, height, body weight, or personal history between the case and control subjects. The BMPRIA gene of all participants were sequenced and 12 SNPs (minor allele frequency in cases $>0.05$ ) were identified and genotyped (Table 2). Alleles and genotype frequencies for all SNPs were in Hardy-Weinberg equilibrium in both groups. Single marker test, which were based on an allergic model, revealed association between an increased risk of OPLL and the minor alleles of rs34755052 $(\mathrm{C} / \mathrm{T})(p<0.05)$ and $\mathrm{rs} 11528010(\mathrm{C} / \mathrm{A})$ $(p<0.05)$.

The Genotype distribution in BMPRIA between OPLL and control groups was compared by Pearson chi-squared test. The result showed significant associations between the occurrence of OPLL and rs34755052 (CC vs. CT vs. TT) $(p<0.05)$ and rs11528010 (CC vs. CA vs. AA) $(p<0.05)$ (Table 3$)$.

To study the contribution of these polymorphisms to the severity or promotion of OPLL, a nonparametric test (Mann-Whitney exact

\begin{tabular}{|c|c|c|c|c|c|c|}
\hline \multirow{2}{*}{ Indices } & \multicolumn{2}{|l|}{ All } & \multicolumn{2}{|l|}{ Male } & \multicolumn{2}{|l|}{ Female } \\
\hline & OPLL & Controls & OPLL & Controls & OPLL & Controls \\
\hline Number & 292 & 586 & 162 & 295 & 130 & 291 \\
\hline Age (years) & $\begin{array}{l}31-77 \\
(55.2 \pm 9.9)\end{array}$ & $28-79(54.8 \pm 7.6)$ & $\begin{array}{l}31-77 \\
(56.9 \pm 10.2)\end{array}$ & $\begin{array}{l}31-79 \\
(55.7 \pm 5.7)\end{array}$ & $\begin{array}{l}34-75 \\
(52.7 \pm 9.0)\end{array}$ & $\begin{array}{l}28-78 \\
(51.6 \pm 7.2)\end{array}$ \\
\hline Weight (kg) & $\begin{array}{l}51-84 \\
(59.7 \pm 6.4)\end{array}$ & $\begin{array}{l}50-85 \\
(59.1 \pm 8.0)\end{array}$ & $\begin{array}{l}63-84 \\
(60.1 \pm 9.4)\end{array}$ & $\begin{array}{l}61-85 \\
(61.3 \pm 6.3)\end{array}$ & $\begin{array}{l}51-71 \\
(57.7 \pm 9.6)\end{array}$ & $\begin{array}{l}50-72 \\
(56.9 \pm 7.8)\end{array}$ \\
\hline Height (cm) & $\begin{array}{l}150-178 \\
(163.1 \pm 6.6)\end{array}$ & $\begin{array}{l}152-180 \\
(164.1 \pm 9.8)\end{array}$ & $\begin{array}{l}165-178 \\
(168.6 \pm 6.3)\end{array}$ & $\begin{array}{l}167-180 \\
(169.3 \pm 3.6)\end{array}$ & $\begin{array}{l}150-170 \\
(158.6 \pm 3.5)\end{array}$ & $\begin{array}{l}152-169 \\
(159.0 \pm 4.4)\end{array}$ \\
\hline \multicolumn{7}{|l|}{ Social History } \\
\hline Smoking (yes) & 118 & 256 & 102 & 234 & 16 & 22 \\
\hline Alcohol use ( $\geq$ once a week) & 86 & 125 & 72 & 121 & 16 & 4 \\
\hline \multicolumn{7}{|l|}{ Sub-type of OPLL } \\
\hline Continuous & 104 & & 56 & & 48 & \\
\hline Mixed & 52 & & 28 & & 24 & \\
\hline Segmental & 116 & & 62 & & 54 & \\
\hline Localized & 20 & & 11 & & 09 & \\
\hline
\end{tabular}

Age, body weight and height are expressed as means \pm SD

Table 1: Clinical and demographic characteristics of the participants in the entire study. 
Citation: Jin W, Yang H, Zhao C, Lin X, Wang H (2013) Association of Bone Morphogenic Protein Receptor IA (BMPIA) Gene Polymorphism with Ossification of Posterior Longitudinal Ligament (OPLL) of the Cervical Spine in a Chinese Han Population. J Spine 2: 131. doi:10.4172/21657939.1000131

Page 3 of 5

\begin{tabular}{|c|c|c|c|c|c|c|c|}
\hline No. & rs-ID & Location and nucleotide position & Allele & Amino acid substitution & MAF (OPLL) & MAF (Control) & $p\left(x^{2}\right)$ \\
\hline 1 & rs 34755052 & $\begin{array}{l}\text { 5'UTR } \\
88516595\end{array}$ & $\mathrm{C} / \mathrm{T}$ & & 0.45 & 0.32 & $0.012^{*}$ \\
\hline 2 & rs 113347633 & $\begin{array}{l}\text { 5'UTR } \\
88635969\end{array}$ & $\mathrm{C} / \mathrm{T}$ & & 0.22 & 0.23 & 0.826 \\
\hline 3 & rs 11528010 & $\begin{array}{l}\text { Exon 3 } \\
88635779\end{array}$ & $\mathrm{C} / \mathrm{A}$ & Pro2Thr & 0.39 & 0.31 & $0.032^{*}$ \\
\hline 4 & rs 17231982 & $\begin{array}{l}\text { Intron 1 } \\
88557849\end{array}$ & $\mathrm{C} / \mathrm{G}$ & & 0.43 & 0.44 & 0.378 \\
\hline 5 & rs 6586039 & $\begin{array}{l}\text { Intron 1 } \\
88568565\end{array}$ & $A / G$ & & 0.49 & 0.48 & 0.419 \\
\hline 6 & rs 10788528 & $\begin{array}{l}\text { Intron } 2 \\
88616771\end{array}$ & $A / G$ & & 0.43 & 0.45 & 0.382 \\
\hline 7 & rs 11202221 & $\begin{array}{l}\text { Intron } 2 \\
88562314\end{array}$ & $A / G$ & & 0.36 & 0.34 & 0.647 \\
\hline 8 & rs 7922846 & $\begin{array}{l}\text { Intron 4 } \\
88641501\end{array}$ & $A / T$ & & 0.40 & 0.38 & 0.419 \\
\hline 9 & rs 10887666 & $\begin{array}{l}\text { Intron } 6 \\
88659047\end{array}$ & $\mathrm{C} / \mathrm{T}$ & & 0.28 & 0.26 & 0.704 \\
\hline 10 & rs 35619497 & $\begin{array}{l}\text { Exon 11 } \\
88681437\end{array}$ & $\mathrm{C} / \mathrm{T}$ & Arg443Cys & 0.30 & 0.28 & 0.482 \\
\hline 11 & rs 55845713 & $\begin{array}{l}\text { Exon } 12 \\
88683185\end{array}$ & $\mathrm{G} / \mathrm{C}$ & Pro465Pro & 0.46 & 0.44 & 0.419 \\
\hline 12 & rs 182970149 & $\begin{array}{l}\text { 3'UTR } \\
88683010\end{array}$ & $\mathrm{C} / \mathrm{T}$ & & 0.39 & 0.37 & 0.638 \\
\hline
\end{tabular}

$p\left(X^{2}\right)$ calculated by chi-squared test (Continuity correction)

Rs-IDs and Location of the 12 SNPs in BMPRIA gene, as well as nucleotide position, amino acid substitution and $p$-values of allele in our cohort are indicated

Table 2: The 12 Identified single nucleotide polymorphism locus in BMPRIA gene.

\begin{tabular}{|c|c|c|c|c|}
\hline \multirow{2}{*}{ SNP No. } & \multirow{2}{*}{ rS-ID } & \multicolumn{2}{|c|}{ Number (AA/AB/BB) } & \multirow{2}{*}{$p\left(x^{2}\right)$} \\
\hline & & OPLL & Control & \\
\hline 1 & rs $34755052(\mathrm{C} / \mathrm{T})$ & $58 / 146 / 88$ & $70 / 234 / 282$ & $0.008^{*}$ \\
\hline 2 & rs $113347633(\mathrm{C} / \mathrm{T})$ & $23 / 82 / 187$ & $41 / 188 / 357$ & 0.336 \\
\hline 3 & rs $11528010(\mathrm{C} / \mathrm{A})$ & $56 / 117 / 119$ & $47 / 270 / 269$ & $0.015^{*}$ \\
\hline 4 & rs $17231982(\mathrm{C} / \mathrm{G})$ & $53 / 146 / 93$ & $100 / 316 / 170$ & 0.478 \\
\hline 5 & rs $6586039(A / G)$ & $58 / 169 / 65$ & $105 / 352 / 170$ & 0.519 \\
\hline 6 & rs $10788528(A / G)$ & $50 / 152 / 90$ & $105 / 293 / 188$ & 0.282 \\
\hline 7 & rs $11202221(\mathrm{~A} / \mathrm{G})$ & $35 / 140 / 117$ & $64 / 270 / 252$ & 0.337 \\
\hline 8 & rs 7922846(A/T) & $35 / 140 / 117$ & $94 / 258 / 234$ & 0.289 \\
\hline 9 & rs $10887666(\mathrm{C} / \mathrm{T})$ & $35 / 93 / 164$ & $53 / 199 / 334$ & 0.684 \\
\hline 10 & rs $35619497(\mathrm{C} / \mathrm{T})$ & $53 / 70 / 169$ & $94 / 141 / 351$ & 0.572 \\
\hline 11 & rs $55845713(\mathrm{G} / \mathrm{C})$ & $70 / 128 / 94$ & $152 / 211 / 223$ & 0.369 \\
\hline \multirow[t]{2}{*}{12} & rs $182970149(\mathrm{C} / \mathrm{T})$ & $53 / 123 / 116$ & $94 / 246 / 246$ & 0.458 \\
\hline & total & 292 & 586 & \\
\hline
\end{tabular}

$p\left(X^{2}\right)$ calculated by Pearson chi-squared test

rs $34755052(\mathrm{C} / \mathrm{T})(\mathrm{CC}$ vs. CT vs. TT) and rs 11528010(C/A) (CC vs. CA vs. AA) show statistical significance $(\mathrm{p}<0.05)$

Table 3: Analysis of genotype distribution in BMPRIA gene between OPLL and control groups.

test) was employed to examined the association between the allele distribution of 12 SNPs and the number of ossified vertebrae in OPLL patient (Figures 1 and 2). There was no significant association between the extent of OPLL and $\mathrm{rs} 34755052(\mathrm{C} / \mathrm{T})(p=0.131)$. But regarding the rs11528010 (C/A) polymorphism, patient with A Allele (genotype, AC or AA) had a significantly greater number of ossified cervical vertebrae compared with patients without the A allele (genotype, CC $p<0.05$ ). The present results indicate that the A allele promotes ectopic ossification in the cervical spine among patients with OPLL.

\section{Discussion}

OPLL was age related, characterized by ectopic ossification in the spine ligaments, and resulted in spinal myelopathy in Asian populations [1]. However, the etiology of this disease had not been clarified. Multiple genetic and environmental components contributed to the development of OPLL. Previous studies indicated that genetic background may play an important role in OPLL pathogenesis.

BMPRIA was one subtype of the bone morphogenetic protein receptor family [24]. Previous studies had demonstrated that BMPRIA was one of the most potent inducers of osteogenic differentiation in vitro [27] and in animal model [28]. Previous case-control studies of fibrodysplasia ossificans progressiva and adolescent idiopathic scoliosis had proved that BMPRIA was a potent modulator of cartilage development in human being, inhibition of BMP type I receptor activity might be useful in treating heterotopic ossification syndromes [29,30] and SNPs changes of BMPRIA might be responsible to the onsets of these diseases. Interestingly, pathological studies found that, BMPRIA was also highly expressed in the ossified ligament tissues of patients with ossification of the posterior longitudinal ligament [31,32]. 
Citation: Jin W, Yang H, Zhao C, Lin X, Wang H (2013) Association of Bone Morphogenic Protein Receptor IA (BMPIA) Gene Polymorphism with Ossification of Posterior Longitudinal Ligament (OPLL) of the Cervical Spine in a Chinese Han Population. J Spine 2: 131. doi:10.4172/21657939.1000131

Page 4 of 5

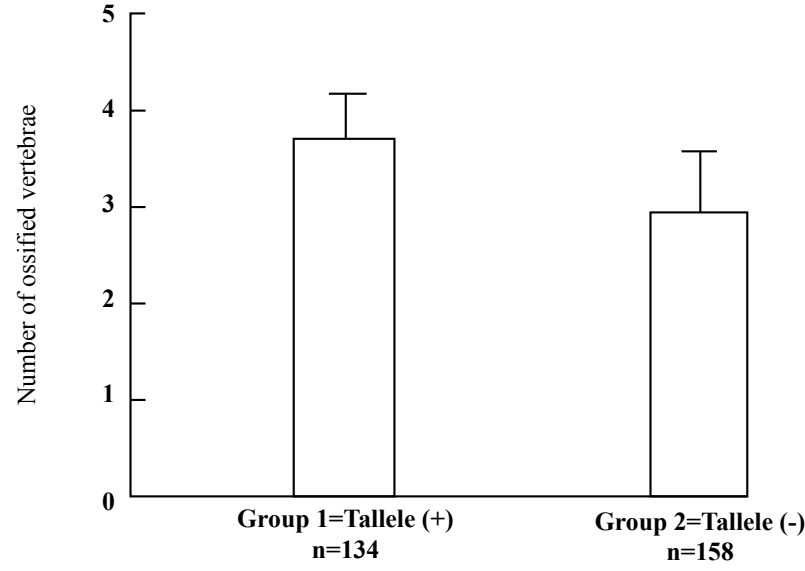

Data are expressed as means (bars) \pm SEM (error bars). The number of patients is shown under each bar. The difference in the number of ossified was not significant

Figure 1: The number of ossified vertebrae of OPLL patients in each subgroup classified by genotype of the rs34755052 (C/T).

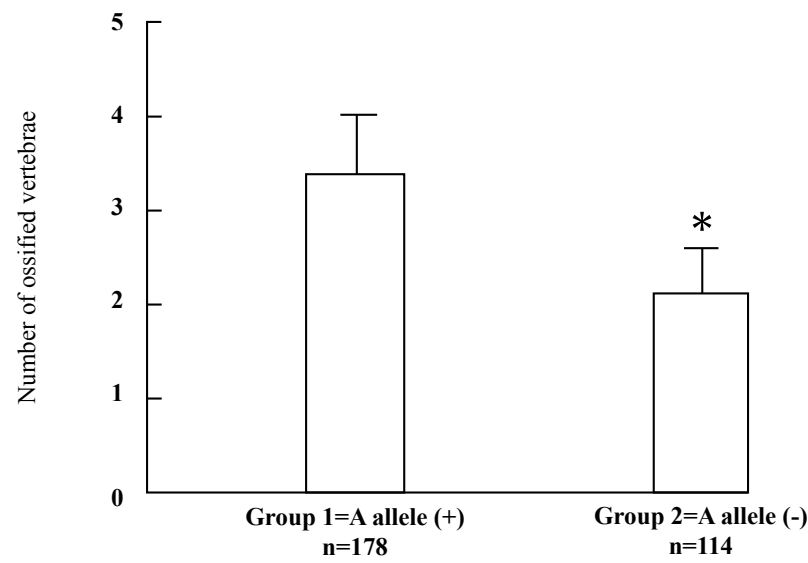

Data are expressed as means (bars) + SEM (error bars). The number of patients is shown under each bar. The difference in the number of ossified vertebrae between carriers (group 1) and non-carriers (group 2) of deletion A allele was statistically analyzed. $\mathrm{P}=0.044$

Figure 2: The number of ossified vertebrae of OPLL patients in each subgroup classified by genotype of rs 11528010 (C/A).

In this study we focused on the role of Bone morphogenetic protein receptor IA (BMPRIA) in the development of OPLL. To confirm that the BMPRIA locus is associated with the occurrence of OPLL, we sequenced the complete $12 \mathrm{~kb}$ BMPRIA genomic region and identified 12 SNPs (Table 2). We analyzed the association between these gene variations and the occurrence of OPLL and found that the alleles of $\mathrm{rs} 34755052(\mathrm{C} / \mathrm{T})$ and $\mathrm{rs} 11528010(\mathrm{C} / \mathrm{A})$ increased risk of OPLL. However, the mechanisms that underlined these associations remained unclear. Given that $\mathrm{rs} 34755052(\mathrm{C} / \mathrm{T})$ was located in upstream of BMPRIA gene, the functional impact of this SNPs on genetic susceptibility to OPLL was still uncertain. Liu et al. [33] found that there were some transcription factor binding sites in the upstream of BMPRIA gene, which impacted on the expression of BMPRIA and resulted in calcification in the cells used to have a poor osteogenetic activity [33,36]. The gene locus of rs34755052 (C/T) was exactly located in one of the transcription factor binding site. We concluded that the change of nucleotide in rs34755052 (C/T) may have effect on the binding of transcription factor with BMPRIA, through which the expression level of the BMPRIA gene changed, and thus resulted in the calcification of the posterior longitudinal ligament. On the other hand, rs 11528010 (C/A), which located in the exon 3 of BMPRIA gene, would result in an amino acid substitution (Pro to Thr). This variation occur in the area where BMPs binding with BMPRIA and may change the structure of BMPRIA, which could change the binding force of BMPRIA with BMP [37]. However, previous study of rs11528010 (C/A) reported that this SNPs had an association with the susceptibility of glycometabolism. And hyperglycemia was one of the most important risk factor with the occurrence of OPLL. So alleles of rs11528010 (C/A) may not be causative itself but a marker for high risk factor related to OPLL.

Moreover, we analyzed the distribution of the number of ossified vertebrae in relation to alleles of rs34755052 (C/T) and rs11528010 (C/A) in OPLL patients. The alleles of rs $34755052(\mathrm{C} / \mathrm{T})$ showed nonrelationship with the severity of OPLL, but rs11528010 (C/A) increased the severity of OPLL significantly. As mentioned before, it is unknown as yet how this SNPs impact on the osteogenetic activity of the ligament cells. Additional studies were needed to reveal the exactly function of this SNPs in BMPRIA gene.

In conclusion, our study provided evidence to support an association between SNPs in BMPRIA and the occurrence of OPLL. The allele T of rs $34755052(\mathrm{C} / \mathrm{T})$ is associated with the severity of OPLL, but not associated with the severity of OPLL. However, the allele A of rs $11528010(\mathrm{C} / \mathrm{A})$ is not only associated with the occurrence of OPLL, but also associated with the severity of OPLL. The result of the current study may contribute to understand the underlying mechanism and genetic etiology of OPLL and lead to further biochemical or gene functional studies.

\section{Acknowledgments}

The authors thank Dr. Yuhuai Jin (Hebei Medical University) for kind support of this study.

\section{References}

1. Sakou T, Matsunaga S, Koga H (2000) Recent progress in the study of pathogenesis of ossification of the posterior longitudinal ligament. J Orthop Sci 5: 310-315.

2. Schmidt MH, Quinones-Hinojosa A, Rosenberg WS (2002) Cervical myelopathy associated with degenerative spine disease and ossification of the posterior longitudinal ligament. Semin Neurol 22: 143-148.

3. Matsunaga S (2009) Updates on ossification of posterior longitudinal ligament Epidemiology and pathogenesis of OPLL. Clin Calcium 19: 1415-1420.

4. Liu KC (1990) Epidemiological study on ossification of the posterior longitudinal ligament (OPLL) in the cervical spine--comparison of the prevalence between Japanese and Taiwanese. Nihon Seikeigeka Gakkai Zasshi 64: 401-408.

5. ZGSC Li ZS (1999) The incidence of the ossification of the posterior longitudinal ligament in northern region of China. Chin J Spine Spinal Cord.

6. Kim TJ, Bae KW, Uhm WS, Kim TH, Joo KB, et al. (2008) Prevalence of ossification of the posterior longitudinal ligament of the cervical spine. Joint Bone Spine 75: 471-474

7. Inamasu J, Guiot BH, Sachs DC (2006) Ossification of the posterior longitudinal ligament: an update on its biology, epidemiology, and natural history. Neurosurgery 58: 1027-1039.

8. Shingyouchi $Y$, Nagahama A, Niida M (1996) Ligamentous ossification of the cervical spine in the late middle-aged Japanese men. Its relation to body mass index and glucose metabolism. Spine (Phila Pa 1976) 21: 2474-2478.

9. Kobashi G, Washio M, Okamoto K, Sasaki S, Yokoyama T, et al. (2004) High body mass index after age 20 and diabetes mellitus are independent risk factors for ossification of the posterior longitudinal ligament of the spine in Japanese subjects: a case-control study in multiple hospitals. Spine (Phila $\mathrm{Pa}$ 1976) 29: 1006-1010. 
Citation: Jin W, Yang H, Zhao C, Lin X, Wang H (2013) Association of Bone Morphogenic Protein Receptor IA (BMPIA) Gene Polymorphism with Ossification of Posterior Longitudinal Ligament (OPLL) of the Cervical Spine in a Chinese Han Population. J Spine 2: 131. doi:10.4172/21657939.1000131

Page 5 of 5

10. Okamoto K, Kobashi G, Washio M, Sasaki S, Yokoyama T, et al. (2004) Dietary habits and risk of ossification of the posterior longitudinal ligaments of the spine (OPLL); findings from a case-control study in Japan. J Bone Miner Metab 22: 612-617.

11. Washio M, Kobashi G, Okamoto K, Sasaki S, Yokoyama T, et al. (2004) Sleeping habit and other life styles in the prime of life and risk for ossification of the posterior longitudinal ligament of the spine (OPLL): a case-control study in Japan. J Epidemiol 14: 168-173.

12. Yamauchi T, Taketomi E, Matsunaga S, Sakou T (1999) Bone mineral density in patients with ossification of the posterior longitudinal ligament in the cervical spine. J Bone Miner Metab 17: 296-300.

13. Matsunaga S, Yamaguchi M, Hayashi K, Sakou T (1999) Genetic analysis of ossification of the posterior longitudinal ligament. Spine (Phila Pa 1976) 24 937-938.

14. Terayama K (1989) Genetic studies on ossification of the posterior longitudina ligament of the spine. Spine (Phila Pa 1976) 14: 1184-1191.

15. Sakou T, Taketomi E, Matsunaga S, Yamaguchi M, Sonoda S, et al. (1991) Genetic study of ossification of the posterior longitudinal ligament in the cervica spine with human leukocyte antigen haplotype. Spine (Phila Pa 1976) 16: 1249-1252.

16. Taketomi E, Sakou T, Matsunaga S, Yamaguchi M (1992) Family study of a twin with ossification of the posterior longitudinal ligament in the cervical spine. Spine (Phila Pa 1976) 17: S55-S56.

17. Kong Q, Ma X, Li F, Guo Z, Qi Q, et al. (2007) COL6A1 polymorphisms associated with ossification of the ligamentum flavum and ossification of the posterior longitudinal ligament. Spine (Phila Pa 1976) 32: 2834-2838.

18. Wang H, Liu D, Yang Z, Tian B, Li J, et al. (2008) Association of bone morphogenetic protein-2 gene polymorphisms with susceptibility to ossification of the posterior longitudinal ligament of the spine and its severity in Chinese patients. Eur Spine J 17: 956-964.

19. Nakamura I, Ikegawa S, Okawa A, Okuda S, Koshizuka Y, et al. (1999) Association of the human NPPS gene with ossification of the posterior longitudinal ligament of the spine (OPLL). Hum Genet 104: 492-497.

20. Kawaguchi Y, Furushima K, Sugimori K, Inoue I, Kimura T (2003) Association between polymorphism of the transforming growth factor-beta1 gene with the radiologic characteristic and ossification of the posterior longitudinal ligament. Spine (Phila Pa 1976) 28: 1424-1426

21. Tahara M, Aiba A, Yamazaki M, Ikeda Y, Goto S, et al. (2005) The exten of ossification of posterior longitudinal ligament of the spine associated with nucleotide pyrophosphatase gene and leptin receptor gene polymorphisms. Spine (Phila Pa 1976) 30: 877-880.

22. Wang EA, Rosen V, Cordes P, Hewick RM, Kriz MJ, et al. (1988) Purification and characterization of other distinct bone-inducing factors. Proc Natl Acad Sci USA 85: 9484-9488.
23. Meng $X L$, Wang $H$, Yang $H$, Hai $Y$, Tian BP, et al. (2010) $T$ allele at site 6007 of bone morphogenetic protein-4 gene increases genetic susceptibility to ossification of the posterior longitudinal ligament in male Chinese Han population. Chin Med J (Engl) 123: 2537-2542.

24. Aström AK, Jin D, Imamura T, Röijer E, Rosenzweig B, et al. (1999) Chromosomal localization of three human genes encoding bone morphogenetic protein receptors. Mamm Genome 10: 299-302.

25. Panchision DM, Pickel JM, Studer L, Lee SH, Turner PA, et al. (2011) Sequential actions of BMP receptors control neural precursor cell production and fate. Genes Dev 15: 2094-2110.

26. Namiki M, Akiyama S, Katagiri T, Suzuki A, Ueno N, et al. (1997) A kinase domain-truncated type I receptor blocks bone morphogenetic protein-2-induced signal transduction in C2C12 myoblasts. J Biol Chem 272: 22046-22052.

27. Wang A, Ding X, Sheng S, Yao Z (2010) Bone morphogenetic protein recepto in the osteogenic differentiation of rat bone marrow stromal cells. Yonsei Med J 51: 740-745

28. Bragdon B, D’Angelo A, Gurski L, Bonor J, Schultz KL, et al. (2012) Altered plasma membrane dynamics of bone morphogenetic protein receptor type la in a low bone mass mouse model. Bone 50: 189-199.

29. Qiang S, Yong Q, Zhen L (2005) Abnormal expression and etiologica significance of BMPR- IA/IB in mesenchymal stem cells from adolescent idiopathic scoliosis. Chinese Journal of Rehabilitation Medicine 810-813.

30. Yu PB, Deng DY, Lai CS, Hong CC, Cuny GD, et al. (2008) BMP type I recepto inhibition reduces heterotopic [corrected] ossification. Nat Med 14: 1363-1369.

31. Yonemori K, Imamura T, Ishidou Y, Okano T, Matsunaga S, et al. (1997) Bone morphogenetic protein receptors and activin receptors are highly expressed in ossified ligament tissues of patients with ossification of the posterior longitudinal ligament. Am J Pathol 150: 1335-1347.

32. Hayashi K, Ishidou Y, Yonemori K, Nagamine T, Origuchi N, et al. (1997) Expression and Localization of bone morphogenetic proteins (BMPs) and BMP Receptors in Ligamenturn Flavum. Bone 21: 23-30.

33. Liu R, Ginn SL, Lek M, North KN, Alexander IE, et al. (2009) Myoblast sensitivity and fibroblast insensitivity to osteogenic conversion by BMP-2 correlates with the expression of Bmpr-1a. BMC Musculoskelet Disord 10: 51.

34. Tsuyama N (1984) Ossification of the posterior longitudinal ligament of the spine. Clin Orthop Relat Res 184: 71-84.

35. Oste C (1988) Polymerase chain reaction. Biotechniques 6: 162-167.

36. Dahdaleh FS, Carr JC, Calva D, Howe JR (2011) SP1 regulates the transcription of BMPR1A. J Surg Res 171: e15-e20.

37. Ren Y, Liu ZZ, Feng J, Wan H, Li JH, et al. (2012) Association of a BMPg haplotype with ossification of the posterior longitudinal ligament (OPLL) in a Chinese population. PLoS One 7: e40587. 